\title{
Historein
}

Vol 3 (2001)

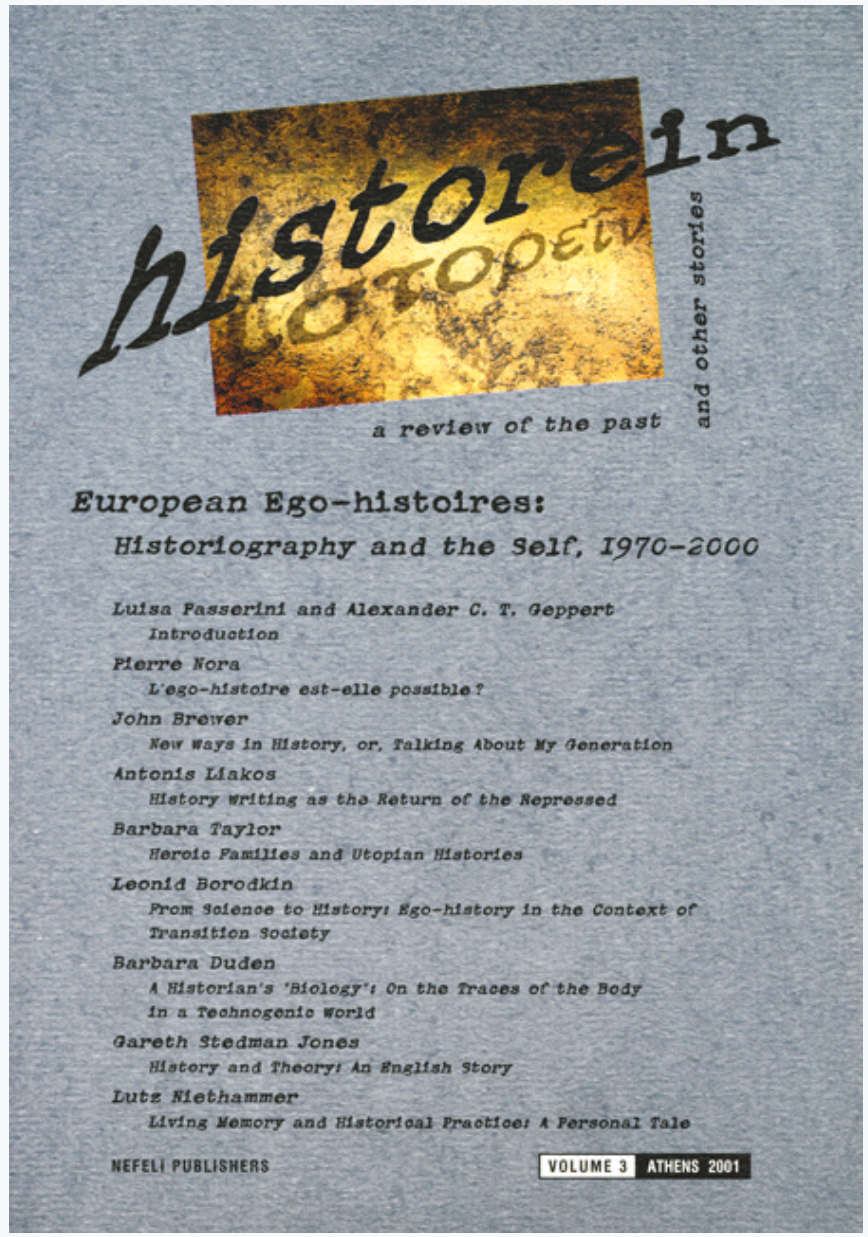

\section{A Historian's "Biology": On the Traces of the Body in a Technogenic World}

Barbara Duden

doi: $\underline{10.12681 / \text { historein.102 }}$

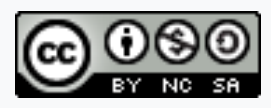

This work is licensed under a Creative Commons Attribution-NonCommercialShareAlike 4.0.

\section{To cite this article:}

Duden, B. (2002). A Historian's "Biology": On the Traces of the Body in a Technogenic World. Historein, 3, 89-102. https://doi.org/10.12681/historein.102 


\section{A Historian's}

\section{"Biology":}

\section{On the Traces}

\section{of the Body in}

\section{a Technogenic}

\section{World}

\section{Barbara Duden}

The invitation to look back on the intellectual genesis of my present stance as a historian and to do so in light of contemporary transformations in the historical disciplines forced me to recognize that one who started out as a historian of the body has come to terms in a new way with her own "biology," the "biology" of a woman now well into her fifties. You asked me to report on "crucial stimuli, decisions and turning-points" on the road I have traveled as a historian. Early on trained to become a historian of woman's body, I cannot help now being astonished to have to relabel myself as a historian of biology.

I take the term biology to mean what its two components say: to "speak" about Bios (bios), which is "an individually lived life-time," corresponding to the Latin curriculum vitae.

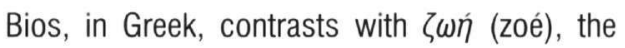
"aliveness of an organic being." The technical term "biology" was first synthesized in 1802 by Treviranus and Lamarck to name a previously unknown field of studies. ${ }^{1}$ In antiquity the term biologos was used for the dramatic performer. By claiming for the ego-historian the status of a biologist, I demand the recognition of performing art as a historical discipline.

Long ago I set out to investigate the historical nature of the female body, which compelled me to make my own "biology" into the conditio sine qua non for the exegesis of the sources I dealt with. In my research I decided to listen to the women who appear in these texts by combining the tradition of textual analysis with a constant search for my sensual syntony with the aches, discomforts and pains of long dead women. My attempt to combine sensual awareness with categorical clarity, to avoid 
sentimentality as much as retrospective diagnosis demanded from me an effort to rethink my own "biology" which, to a large degree, reflects assumptions, perceptions, feelings and projections of a woman my epoch and age.

Ego-history in my case will be unavoidably bio-logy, the ruminations of a post-war woman who has based her historical research on the belief that a patient pursuit of sensual syntony with long dead women would allow her to aim beyond analytic bio-graphy of the dead and permit her in some way to recover traces of their bio-logia. To capture and transmit to her contemporaries not just the content, but the timbre of the voice with which each woman tells of the burden she bears. As a result, much of what I will have to say, is an account of decisive turns in my own past, a sequence of memories about changes in my mode of intellectual and sensual perceptions. A report on those moments that made me into a fence rider with one foot dangling in accepted historiography based on today's conventional certainties, and the other reaching out for a foothold in the somatic certainties of the early eighteenth century. I will report on myself as a commuter between distant periods, as one who had to learn how to embody the pastness of "biology" in her own present. And I got used to speaking of my own present, my felt presence as "somatic," to stress the non-conceptualized dimension of this autoception.

\section{Fence Riding in the Now}

I teach gender studies in the Department of Sociology of Hanover's huge former polytechnic. For many months of the year it is my duty to guide students through the maze of sociological abstractions. I act as a Zwitterwesen, a cross between a historian and social scientist. I have tried, and in a way I have succeeded, to make the somatic autoception of women in the early eighteenth century into a legitimate subject. In my seminars we often return to the same question: What was the stuff that women alluded to when they spoke about their "blood" or the "fruit of their womb," their open legs, their stagnations, their disorderly fluxes?

To make this kind of inquiry a fruitful undertaking, I had to be frank with myself. I had to ask: "Why do these women strike me as aliens? Why do they irritate me when they speak about their monthlies or angers? Why do they succeed in making me feel ashamed to be a woman like them?" It was not easy for me to make sense out of their alien flesh and blood. Years before I dared to teach history of the body I had had to face my own sensual malaise. Only slowly I accepted that the historical research I had chosen demands from the practitioner to alienate herself from the certainties which had been bred into her.

Step by step I realized that my own senses - my own autoception - had been molded by the certainties of the "normative biology" of the ' 50 s and ' 60 s, the years when I grew up. In order to open myself - my carnal being - to the past (um mich leibhaftig der Vergangenheit zu öffnen), I began to train myself in a new way of looking and feeling: I trained myself to perceive myself with the eyes of the past. My effort to understand how women at the time of Johann Sebastian Bach might have "sensed" themselves, has forced me into an acute awareness of the 
historicity of my own, present-day autoception. Only by practicing this ascesis could I approach the reality of the women in my sources. It was only by accepting the insights gained by this exercise in syntony that enabled me to try a sociological analysis of the technogenic, epochal transformations and re-definitions of woman's body in contemporary society. A constant attempt at a somatically meaningful exegesis of old texts thus fostered a habitual and disciplined epistemic liminality.

The art that I try to teach to my students is the habit of viewing both the past and their own present from a distance, I train them into the habit of fence riding. Without mercy I demand from my students a ridge walk. I ask them to keep a balance between the appropriate methods for liminality both with respect to the past and the present. My students are registered in sociology and cannot escape those courses in which they are taught to view women's lives through the spectacles of contemporary theory: ${ }^{2}$ agency, fractured identity, actual competence, role-models and ascriptions, chances in autonomy, double-orientation, structural needs, ambiguous development, and sexual difference. What I demand from them aims at counterbalancing these flat abstractions. I want them to understand what a woman meant, when, in 1717 , she complained to her physician about a "swelling fury." I challenge them to take their example from the physician who attentively listens to a patient who reports that, after a run-in with her arrogant landlord, her anger coagulated into a knot that now resides in her belly and tears her apart. A knot that she has been unable to dissolve by taking tincture of rhubarb.

\section{The Past in Me}

By choosing disciplined liminality as a method for research, I accepted marginality in both mainstream sociology and in history. I use the past as my path into the present. To do so I had to dare estranging myself from my own generation, which takes disembodiment for granted. After more than a decade of my quest for empathy with past modes of embodiment, I felt equipped to test the meaning of textual passages for the sensual response they evoked in my own soma. I felt entitled to say to myself that she who engages in this concrete exegesis is Barbara, not any historian, and still less any sociologist. I often remember the lemma of Ortega y Gasset, "yo soy yo y mis circunstancias," and apply it to myself by adding "las circunstancias historicas de mi encarnación." Daring an extended pilgrimage in search of past "bodies," the deeper my awareness became that in my own constitution I came to be indebted to my subjects. The search of the flesh and blood as the soil of history forced me to face what it means to be - no, to live - the bios of a historian. Paolo Prodi beautifully expresses what I want to convey:

All'interno dello sviluppo delle scienze moderne, la storia si e proclamata come la disciplina che non studia genericamente il passato (in questo si identificherebbe con l'antiquariato), ma il passato che è in noi, in funzione dell'oggi. ${ }^{3}$

Prodi is commenting here on Droysen: "History is the science that studies the past in us and does so in view of the present." 
To say "the body" is a way of referring to that exquisite theme of the historian that cannot be explored without training one's own sensibilities rooted in the present and shaped by it. And this training demands the constant shuttling between the testimonies of past embodiment and one's own somatic habits. Let me assure you from my experience which is now confirmed by years of teaching younger women: from year to year this back and forth, between somatic autoception then and now, requires more daring. My students are trained to perceive themselves as systemic processes, and this detaches the meaning they give to flesh and blood (Leibhaftigkeit) from the stuff which brought forth and nourished all earlier epochs. I will come to speak of this more, but first let me take a look at the bio-bibliography of Barbara Duden, who, once upon a time, felt compelled to attach to herself the labels "historian" and "woman."

\section{My Bio-bibliography}

I started out with an investigation of Berlin's eighteenth century Jewish Salonièrs (my MA thesis in 1971). Soon afterwards I began to reclaim the "body" as a historical theme. In The Woman beneath the Skin I set out to interpret eight volumes of an early eighteenth century provincial physician's diary attempting to recover what women meant when referring to their "bodies." Almost at the same time I worked on a polemical essay focusing on the fetal image as emblem for "life," ${ }^{5}$ followed by the Anatomy of Good Hope (in German), the history of anatomical depictions of the unborn in printed atlases. ${ }^{6}$ With the background and the assurance gained in these historical studies, I dared to clarify a key issue of contemporary history - a watershed that divides my youth from my present. I undertook numerous excursions into the recent history of cancerscreening, the pill, menopause, menstruation, abortion, and birth, focusing on what the use of the corresponding techniques "says" about how they shape autoception. This led me during the late ' 90 s to review what is known about the history of ideas dealing with the function of the sense organs, principally the history of opsis, the epochal changes that have occurred not so much in theoretical disquisitions about looking and seeing, but the contrast between the autoception of "grasping" the visible with the ray coming from the eye and the registration of light-rays carrying messages. ${ }^{7}$ Now my most pressing investigation is concerned with the emergence at the end of the millennium of the "bio-optimal woman" as the figment of the health system. Some critics might frown at the time-span in which I have dared to move: from Greek antiquity and Galenus to the seventeenth century, and then on to theory and technique in the late twentieth century.

Underneath this heterogeneity of topics and diversity of periods, I tried to approach my theme by ever-new routes which, most of the time, turned out to be complementary to one another. Allow me to mention a few:

1. The history of syn-aisthesis, above all the demise of the sense of proportionality which was usually referred to as "common sense." A long series of learned disputes about the location of the appropriate organ witness to the sensual rather than conceptual function that was attributed to this faculty. Common sense was the "organ" by which inner balance, appropriate fit, and 
proportionate complementarity was felt, as well as the suitable warmth, seemly orientation, and degree of liquidity appropriate for a certain character and status. I learned to connect the forfeiture of the common sense among the bodily faculties with the fading of proportionality, harmony and natural fit as cultural key-concepts, which led in ethics to the replacement of the good by values.

2. Engagement in the history of the senses was another aspect of the history of the soma that I could not avoid, above all the history of the gaze which Ivan Illich and I call "historical opsis." This is something distinct from the history of optics. ${ }^{8}$ Opsis is concerned with the eye's emission, with the gaze, while optics deals with the ray of the sun and its performance. The perception of the soma has a - now barely understandable - weight and complexity in an epoch in which it is one element of a group of fundamental certainties that we are endowed with active psychopodia, limbs of the soul that spring from the erectile pupil or ear to grasp their object. ${ }^{9}$

3. The history of anatomical representations and the style of their graphic illustrations were most important to recognition of the degree to which popular feelings of the body shaped learned opinions about it. The prime instance which has allowed me to elucidate this point has been the graphic representation of the invisible: the iconography of the unborn, which only around 1800 assumes the likeness of today's public traits of the fetus.

4. Another complementary road on which to investigate historical somatics was the epochspecific felt differences of gender: the contrast between the dissymmetric but mutually constitutive complementarity between men and women differently articulated in each culture and the polarization of sexual differences that is fundamental to the modern notion of sex.

5. I myself have spent much time explaining to academics and above all to midwives the epistemic status of a woman's knowledge of her pregnancy as distinct from its medical, philosophical and artistic portraiture. Pregnancy is a privileged instance in which to grasp the heterogeneity of somatic autoception in different historical periods, the contrast between going pregnant as the state of a woman and diagnosed pregnancy, a type of hexis for which there was no true equivalent in former times.

6 . Both the way this exceptional state is intuited and the way it is the outcome of self-attributed diagnosis depends to a large extent on the overarching assumptions about knowledge that are dominant in a society. I learned to distinguish pregnancy under conditions where knowledge is the result of a pursuit of truth, and knowledge that is determined by its degree of certainty. This led me to differentiate between the awareness of "going pregnant" and the acceptance of the diagnosed state and status of pregnancy. In turn, from the specific contrast between "going pregnant" and "tested pregnancy" I concluded on the much more general contrast between lived and diagnosed self-perception.

7. Finally, I have analyzed transformations of pregnancy in this latter sense, which has come about through the popularization of techniques of visualization. I have spent much time on this interface between the pregnant woman and various photographic, sonographic, and digital abstractions that define her, again graphically, as an "at-risk" member of a statistical population. 
There is ever more evidence of the intensity with which this identification of the "felt self" with its mechanical facsimile is concomitant with the prenatal disembodiment of her fruit, and not just of herself..$^{10}$

\section{Memories of Two Women}

Looking back on these ever renewed efforts to find the appropriate way to grasp the fundamentals of women's somatic experiences, I now recognize a crucial circumstance that has shaped my own history. I say "circumstance" because I fear that if I speak of the "cause" of my fundamental quest I might all too easily be misunderstood. I would speak of cause in one of the four senses given to it by Aristotle, the one he calls telos, the causa finalis. Today's philosophers have almost forgotten it. For the entire peripatetic tradition, nothing moves, nothing comes into being without a telos, without being lured, enticed, called and sometimes just tempted to come into being. What brought my curiosity into being were two women, one of them my twin. In her I discovered the nameless force that pushed my endeavors forward while remaining transparent as a horizon to which I struggled to arrive. I will illustrate this causa finalis that attracted me to undertake the pilgrimage by first telling you about Alexa, who held on to me as I came into this world. Only then will I report on my encounter with a haggard widow in 1723. Both mark turning points in my stance towards "body."

\section{Alexa}

When Alexa, my twin, was born, she squeezed my umbilical cord in her little fist. As quickly as possible, they had to get me out. For the next sixteen years, we fitted one another. While riding her bicycle, she was run over by a truck and was killed. We were real twins, not just uterine sisters. We were alike, right up to our ears. It was by our ears that it was easy to distinguish us: both my ears stuck out perpendicular to the head - Alexa's left ear was as expected, only her right ear pleased our Pomeranian nurse who said that, at home, such ears were the sign of the best pigs, the ones that were easy to fatten.

Alexa's left leg was a bit shorter than the other, so she always limped. And ever since I can remember, her little left arm flapped, it swayed like the wing of a bird. When we reached school age, she started having seizures, yet, right after the spell passed, her spirit was exuberant. Because father did not want her to be put down by teachers, she was taught at home. With just one hand she knitted and rode her bike. For fifteen years, for me she was Alexa, Alexa, the way she was meant to be. We did not compare ourselves.

Then mother took her to the Heidelberg Clinic, at that time the most famous in Europe. What mother brought back was a diagnosis - and it was by virtue of this verdict of science that everything changed. The great man in the clinic had established that Alexa had a brain the size of a bird's. He had no explanation how come Alexa was still so balanced, so joyful and fit. But, so he predicted, soon Alexa would lose her pep, her mobility, her very senses. A high probability accompanied the prognosis; for me it carried the weight of certainty. 
I will never forget the day of Alexa's return, but I never revealed my feeling to anyone. In fact, I still do not find the right word for what happened at that moment: what happened to me, to Alexa, to our accustomed fit. Something, no, everything, changed. Was it a loss of innocence? The evaporation of an atmosphere? A distortion of the uncanny, mutual gaze between twins? Certainly, from that day forward a diagnostic category interfered with my sense of the person Alexa. She had become a case, and some of the sticky stigma of a professional opinion remained glued to my feelings for her. Where previously undisturbed mutual presence had reigned, now the physician's judgment hung over us like a dark cloud. The Heidelberg professor predicted that, with the onset of her monthlies, she would become bulimic - fat, aggressive and stupid. Whenever Alexa took a second serving of porridge, I now imagined a disordered craving. I was left alone to face a future in a world in which my twin would never fit.

To have a twin sister like Alexa was something very precious. My first fifteen years with her were an exceptionally privileged initiation to a non-diagnostic gaze. Imagine! Looking at my spitting image, with only one pig-ear sticking out. Looking at my likeness who, unlike me, flaps with her left wing; one who occasionally trembles and after a frightening convulsion, delights me with infectious joy! Imagine such a challenging initiation to both the "I" and "Thou"! To otherness and to likeness. As well as the kind of initiation to the devastating power of diagnosis that made Alexa into a case.

It was much later that I began to reason about the power of the professional gaze, and, worse, the power of its popularization. The memory of my betrayal of Alexa implanted in me a historically premature horror of diagnostics. I grew up in the ' 50 s, when in Germany six out of ten women gave birth assisted only by a midwife; the time when health insurances had to entice pregnant women with a cash payment to submit to prenatal controls; the time when "prevention" ranked low on the list of health-measures. I can remember the reluctance to self-categorization that came from intuitive, gut knowledge that is now gone.

My students today, trained in feminist sociology, speak about themselves as "social constructs," feel themselves to be the writ of social programming or the epiphenomenon of a genetic text. My students, and not only the biologists among them, take for granted being phenotypes, a read-out of their genotype, their genome. I teach students who have been taught to consider their selfobjectivation as "progress." Daily I converse with young women who use mathematical signs in ordinary conversation, undergraduates who confuse their own expectations from life with the average chance of success in a population; people who say that he, she or it is a risk, or who say "Barbara is a system." In remembering the taste of me and my alter ego, Alexa, I find a foothold, an intuitive gut-perception, that allows me to stand up against this lamentable disorientation-by-misplaced-concreteness.

Losing Alexa one year before her death has given me reason and strength to avoid epistemic traps: the invitation to insert my self in population statistics, microbiological elements, genetic programming and system thinking. I learned that it is impossible to engage in a 
truthful controversy that presupposes that the body can be dealt with as a discursive instance, and that I conspire in this self-objectivation. I would transmogrify myself into one of Emily Martin's Flexible Bodies. ${ }^{11}$

Growing into a historian of the body, I searched how to forge the heuristic and exegetical tools that would enable me to investigate the symbolic body-building results of the encounter between women and bio-medicine. The decisive clue to grasp the genesis of medicine, the rise of new constellations of power and new control of the body was given to us by Michel Foucault's "clinical gaze," the reconstruction of the body laid out horizontally as a corpse in a clinical setting. ${ }^{12}$ In Medical Nemesis, Ivan Illich also pointed us to "symbolic iatrogenesis" and the medicalization of "health." ${ }^{13}$ But neither Foucault nor Illich probed deeper into the transmogrification - or, may I say, the historical trans-substantiation - of experienced somatics, i.e. the innocently factual to the factitiously sensual points of reference of the ego. They did not address the more fundamental issue of modern disembodiment, that is, the abyss that opens only as a result of clinical medicine: the abyss between fluid autoception and the diagnosed body, the transformation from dialectic to diagnostic practice, from one listening to the person to one auscultating a body. And, unfortunately, professional medical historians have been reluctant to give flesh and blood to their "histories": they have stopped short of the experienced body. The patient is strangely missing in the work of these historians - with the exception of a few like the great Lain Entralgo, who knew that

medicine formerly was not the result of the application of a series of abstract sciences in the knowledge and treatment of sickness (...), but a practical knowledge which has at its object a 'subject,' the ailing person... definitely it revolves around practical judgment; ... more than a science, medicine is a practice. ${ }^{14}$

\section{The Haggard Widow}

The memory of the diagnosis that - for me - for her last year of life transformed Alexa from twinsister into case, became a nagging obsession. The surrender to diagnosis loomed ever larger as a fundamental but generally overlooked characteristic of our time. Conceptual compliance with imputed notions and feelings appeared to me a worthy subject of historical study. Yielding obedience to the classifying scrutiny of an observer, especially in matters of self-perception, became for me a moral issue. Cringing at the betrayal of my fifteen-year old twin, I also had to recognize that living under the aegis of diagnosis in the decades since then has become the standard mode of behavior on which I had to gain perspective by reviewing it in past perspective.

My search of the "ailing subject" led to my encounter with a "haggard widow" who became and remained for me the emblem marking the turn to the past. The blood of this one old woman from Eisenach refined my enterprise: out of an attempt at the history of the body grew a "historical somatology." The haggard widow challenged me to search for the epoch-specific modes of expressing the somatic referent of the grammatical first person singular, the flesh and blood of the speaker, the substance of the speaking "I." First let me tell the story of this old hag, of whom 
I know through the diary of the physician she visited in the summer of 1723 . And then let me trace the trail of puzzlement on which my acquaintance with her has launched me.

On July 29th, a haggard, choleric widow comes to see me, a woman well into her seventies. She complains about tearing pains that run down from hip to toe and force her into a limp. When I inquired into the origins of her pain, she confesses that, until two months ago, her monthlies (sic!) had come as usual. In her opinion the onset of pain is due to the stoppage of her monthly bleeding. Since this woman had never been in the habit of taking medicine, I advise her to expose her leg and privy parts to the vapors of boiling milk. (...). Shortly afterwards, her monthlies returned, and the pain ceased. ${ }^{15}$

The story does not stop here. Five years later the same old woman calls once more on the physician. As in the previous visit, the first thing mentioned is the fact that her monthlies had stopped again, this time almost two years back. However, this time she complains about nosebleeds and is upset by dizzy spells. In this second diary entry, Dr. Storch, the physician, adds a remark on the monthlies of his patient's sister "who is now over eighty and whose menses have never faltered and who, throughout life, has always enjoyed good health." ${ }^{16}$

I vividly remember, how stories like this one used to bother, vex, and irk me. The memories of embarrassment, the instances of overlooking key issues, the souvenirs of resistance at even reading poignant passages are parts of ego-history, as are the recollections of physically upsetting insights. I could not stop from wanting to know about the nature of that thing called "blood" that is discussed here between physician and patient. What was it the physician thought he was doing with his prescriptions? Today, no physician in his right mind would react to a patient like Dr. Storch. He would never connect pain in the hip and down the leg with the patient's "flow of blood." He would be appalled by the widow's report of uninterrupted, postmenopausal vaginal bleeding, and probably question her sanity. He would refer her either to a psychiatrist or to an oncologist. If today the woman happened to bring her complaint to a gynecologist, without ado he would manually explore hor vagina instead of listening to her story. To the best of my knowledge, vapors of warm milk applied to the privy parts do not induce monthly flows today, certainly not in an old woman. Today, there just is no physiological connection between nose-bleeds and menses. In Eisenach, strangely but unquestionably, sympathy between the two body exits was a commonly recognized fact. It was a fact for the university trained physician as much as for the widow. For them, blood that was "disoriented" and that therefore could not find its appropriate exit through a lower bodily opening would seek its outlet from an upper part - say, the nose or mouth. Based on these certainties about blood and its "habits," and the body's orientation and possible disorientation, the physician tries to re-orient the old woman's flows.

In reading the story of this old woman I encountered something that I found extremely difficult to grasp; something I would rather not even face, so to speak. The categorical tools that the social sciences had forged, notions such as the humoral pathology of medical historians or the 
social construction of a fluid body used by sociologists, obviously were inadequate to understanding the widow. As I became familiar with innumerable other "woman-patients" (the baroque term), I found that they all speak about their biology in terms of something exquisitely liquid. They speak about their "Geblüt," about fluxes, inner fluid motions (Flussregungen) and of the imbalance of their juices. Their complaints to the physician revolved around something that is foreign, as much to the modern clinic as to the register of symptoms or syndromes that is usually attended to in the history of nosology. Initiated to this insight by the self-perception of German-speaking women of the early eighteenth century, my inner ear became sensitive to a long tradition of autoception in the West reaching back into the middle ages and antiquity, a tradition that insensitive translations had so far hidden from me. The bio-logy of women always found its expression in terms of somatic stirring, of a swelling and ebbing of innermost liquids, and the fear of inner hardening and lumping that the woman perceives as stagnation (Verstockung). ${ }^{17}$ Women are driven to the physician by a stubborn anxiety that their Geblüt might stop, that their fluxes would cease.

My attempt to understand the haptic fluidity at the center of their autoception moved into the focus of my research projects. I speak of "haptic" fluidity, because what I refer to is literally a hapsis, an inner "grasp." I had to go beyond just shifting my attention or readjusting the angle of my vision. I had to rethink the liquid substance of body history. I had to "attune" myself to the kind of almost extinct experience by discovering the echo of these past flows in myself. Finally I had to rescue terms and categories that would reach out to the pre-Cartesian lived bios that was embodied in these bio-logies. I began to grope for methods that would enable me not to decipher the description of a past entitative "body," but "listen" to the "voice" of the suffering woman.

I read and re-read my sources. I let them stir my own autoception. I let these narratives upset my habitual mode of perception. I tried to listen to the patients with the ear of their doctor. I thus had to sharpen my ear for the narrative about the fluent character of historical soma. As a consequence it dawned on me that "body" as discussed recently among historians is consistently misunderstood as something entitative, while in the sources it is an equivalent of the somatic autoception of the conditio humana. A synonym of living the tragic human condition. Listening in this way to the torrents of complaints of women in pain and the effort to make sense of their long-dead physician's attention became for me - as a historian - a painful, embarrassing, sometimes sickening task. As limited as my own ability for mimesis with these women of yore might be, I had to open my own sense of self to the flow of their speech to recover a feel for their bodies from the written trace it has left.

I had to risk my inbred sense of self to get the feel of the dead beast from the tracks it has left. I tried to squeeze the eighteenth century "text" about the widow's nosebleed until, through mimesis, it yielded a sense of what it feels to be in her shoes. I tried to emulate the physician who "grasps" the meaning of this perverted flow and does so by mimesis with the yarn that she spins out for him. I got more and more involved with the narrative character of baroque 
anamnesis of a soma that finds its voice in stories, reports, tales and complaints much more than in definitions or doctrines. The liquid soma implied in those griping women's ego is trans-categorical, it is dramatic.

What goes on in the dialogue between the woman patient who is at the end of her "patience" her ability to bear her condition - and the physician who listens to her, does not lead to that which today we call "a diagnosis." It does not lead to a set of observations (operational verifications) by the physician that results in the medical imputation of a state of illness or health. The medicine practiced in 1723 by an ever so learned town physician is still steeped in a millennial oral tradition. The emblem for the medical stance when facing the patient is not the interpretation of a profile made up of operationally verified observations but the skill of the spectator at a tragic theatre performance. The relief given to the widow by the vapors of cow-milk to her privy parts might perhaps be best understood as an effective rhetorical device, a deus ex machina.

My attempt to make sense out of the widow's flows led me to recent studies of the break involved in the shift from acoustics to optics during the time of Aristotle. ${ }^{18}$ In the Poetics Aristotle disagrees with Plato, his idealist teacher. Unlike Plato, he insists that the theater-goer aims beyond the mere understanding and interpretation of the tragic actor's words. He demands that the spectator allows himself to be touched by the actor's voice, by its sound, rhythm, strength and melody. He exhorts the audience to "hear with the innards." The good actor is he who succeeds in touching and moving, and the competent spectator is he who lets himself be mimetically transported, carried away to grasp the essential of the play: the stance in which the hero stands up and succumbs to the conflicting currents of destiny. The paragraphs of the Poetics that bespeak destiny as the exposure to whirling flows gave me a clue to the haptic quality of the patient's references to herself and to the mimetic way in which the physician allowed himself to be affected by the tragic narration, sharing literally in the bio-logia of the complaining patient. And, believe me, this made me discover the formerly unsuspected threat to the historian's epoch-specific integrity if she allows herself to take the old physician as her model of textual exegesis.

In her magnificent In and Out of the Mind, Ruth Padel shows the rich harvest of new insights which a Greek scholar can gather when she is willing to let the text upset the sensual certainties in which she was raised. She struggled with the historian's difficulty to find the right words to interpret the liquid nature of ancient bio-logy. And, further, Padel is one of the rare authors writing towards recovering the "voice" of the speaker in that special grammatical instance when this voice refers to the speaker, when the speaker says "I." She searches for these instances in pre-classical Greek epic, medicine, and above all dramatic works. She insists that she is "not treating their work as theory, ${ }^{19}$ or does not turn these testimonies into objects of an analysis. Like myself she believes that she can listen to the imagery in the theories, "so that their concreteness can resonate against the poet's language of mind and feeling. (...) Emotional and intellectual events are not merely describable in the same terms as physical movement: they are physical movement." ${ }^{20}$ 
Padel dares to bare the "flux of feeling," she recognizes the often painful methodological demands of self-denial that are the condition for the historical study of "tragedy (that) often suggests that thought, feeling, or any other inner change (such as disease) is moving liquid, something swelling, flowing within. Greek philosophers and medical writers illustrate what tragic imagery implies: that thought and feeling are at work in the blood... Blood boils in emotion... 'boiling' happens particularly in anger. Not just blood, but also other inner liquids, cholos, thymos, menos: black, bitter, raging, they rise in the innards like waves." ${ }^{21}$

I have heard many similar voices in the early eighteenth century, albeit tinged with the particular Protestant physician's emphasis on the blockage, obstruction and stagnation of fluids. From my own, sometimes embarrassing experience, I know something of the intensity with which twentieth century upbringing has numbed the historian's ear for accounts of ever flowing, ever evanescent bio-logy. ${ }^{22}$

\section{The Historian and Her Second Nature}

Most of my colleagues, not to speak of my students in Hanover, have an "ego," a substantive "self," if not an identity which they pursue. It is sometimes not easy to convince them that the vague notion of such an entitative referent of the first person singular is of recent origin; that it fits the body we have, not the ever spouting, gushing, gurgling stuff of yore. If there be such a discipline as ego-history, it presupposes as a prolegomenon the history of ego necessary to reflect on the encounter of the historian as a person with those who are now dead. For me at least it was through such encounters that my biology was shaped, and that is the reason why I built my argument around the place within it of my twin and of that old woman from Eisenach. I hope to have made it plausible that I for one could not have pursued historical somatics unless I had accepted the challenge that encounters of this kind imposed on me as historian. Certainly, to become more competent as a historian I had to work at the improvement of my own critical intellectual habits. I had to refine my intellectual perspectiva as the art and habit not only of perception but of visual cognition. ${ }^{23}$ In turn, my attempt to pursue historical somatics demanded from me the refinement of my sensorium, the cultivation of haptic mimesis, the reawakening of inner senses, above all trust in the survival of my common sense. And, in order to legitimate this attuning - the training for "gut feelings for the past" - as an integral part of a historical method, I had to legitimate it by pursuing the history of sense perception. For several years I conducted a seminar on the history of the mimetic gaze that went out radar-like to grasp its object, while I was trained to use my eye as a registering organ (a device comparable to the VCR). At the time I did my studies at the Technical University in Berlin in the early eighties, I never thought that for my chosen field of historical research would have to train such sensual habits of self-distancing, that I would have to assume respons.bility for what the Greeks called second nature. 
How far this somatic attuning can be pursued by me or any other historian launched on the same task, I do not know. Certainly, this body history - thus understood reflexively - puts the historian into a liminal position, makes her a wanderer (commuter) between her fluid "I" as her own presence, her present incorporation of medicine's "body," and her quest for past voices. This attempt at a disciplined research into the somatic referent of the ego - the soma as the vanishing point of the deixis (the horizon to which the pronoun of the first person points) implied in the self-reference of the speaker - presupposes what in Western tradition has been called ascesis, the yoga of conscious and disciplined abstention from disembodying rituals. In an age of popularized genetics, which foster the fantasy that each one, after all, is but a text, it is the encountered past that I embody that fosters a distanced stance.

${ }^{1}$ William F. Bynum, E. J. Browne, Roy Porter (eds.), Dictionary of the History of Science. Princeton: Princeton University Press, 1981, p. 43. Both authors "by coining the term 'biology' (...) were identifying a new field of study rather than just giving a name to an old one."

${ }^{2}$ From a presentation on "Concepts of individualization and the analysis of female forms of living" (Individualisierungskonzepte und Analyse weiblicher Lebensformen) at the Convention of Sociologists.

${ }^{3}$ Paolo Prodi, Introduzione allo Studio della Storia Moderna. Milano: Mulino, 1999, p. 15.

${ }^{4}$ Barbara Duden, The Woman beneath the Skin. A Doctor's Patients in Eighteenth-Century Germany. Cambridge: Harvard University Press, 1991.

${ }^{5}$ Barbara Duden, Disembodying Women. Perspectives on Pregnancy and the Unborn. Cambridge: Cambridge University Press, 1993.

${ }^{6}$ Barbara Duden, Anatomie der Guten Hoffnung. Stuttgart: Klett-Cotta (forthcoming).

${ }^{7}$ Barbara Duden and Ivan Illich, "Die skopische Vergangenheit Europas und die Ethik des Opsis. Plädoyer für eine Geschichte des Blickes und Blickens," Historische Anthropologie, 3, 2 (1995), pp. 203-221.

${ }^{8}$ See Ivan Illich, "Die Askese des Blicks im Zeitalter der Show - INTERFACE," in Klaus Peter Dencker (ed.), Weltbilder - Bildwelten. Computergestützte Visionen. Hamburg: Hans-Bredow-Institut, 1995, pp. 206-22.

${ }^{9}$ The historian who analyzed the sources in the history of optics as an index not of another knowledge system, but as an index of a different categorical treatment of experience is Gérard Simon, Le Regard, l'être et l'apparance dans l'optique de l'antiquité. Paris: Editions du Seuil, 1988.

${ }^{10}$ Barbara Duden, "I non nati," in Claudio Pancino (ed.), Corpi. Storia, metafore, rappresentazioni fra Medioevo ed età contemporanea. Venice: Marsilio Editori, 2000, pp. 121-36.

${ }^{11}$ Emily Martin, Flexible Bodies. Tracking Immunity in American Culture. From the Days of Polio to the Age of AIDS. Boston: Beacon, 1994.

${ }^{12}$ Michel Foucault, The Birth of the Clinic. New York: Vintage, 1973. 
${ }^{13}$ Ivan Illich, Die Nemesis der Medizin. Die Kritik der Medikalisierung des Lebens. München: Beck, 1994.

${ }^{14}$ Lain Entralgo, El diagnostico medico. Historia e theoria. Barcelona: Salvat, 1982, p. 411.

${ }^{15}$ Johann Storch, Von Kranckheiten der Weiber. Achter Band: Von Gebrechen und Kranckheiten, so man der weiblichen Mutter zuschreibt. Gotha, 1751, p. 277.

${ }^{16}$ Ibid., p. 278.

${ }^{17}$ Gianna Pomata, (La promessa di Guarigione. Malati e curatori in antico regime. Bologna XVI-XVIII seco10. Rome/Bari: Laterza, 1994, pp. 247-85) encountered similar complaints about the "mal d'oppilazione," the sickness of obstruction of fluids in front of the Bolognese Protomedicato. See also idem, "Uomini mestruanti. Somiglianza e differenza fra i sessi in Europa in età moderna," Quaderni storici, 79 (1992), pp. 51-103.

${ }^{18}$ I was inspired by P. Christopher Smith, "From Acoustics to Optics: The Rise of the Metaphysical and the Demise of the Melodic in Aristotle's Poetics," in David Michael Levin (ed.), Sites of Vision. The Discursive Construction of Sight in the History of Philosophy. Cambridge, MA: MIT Press, 1997, pp. 69-91.

${ }^{19}$ Ruth Padel, In and Out of the Mind. Greek Images of the Tragic Self. Princeton: Princeton University Press, 1992, p. 43.

${ }^{20}$ Padel, In and Out, p. 43.

${ }^{21}$ Padel, In and Out, p. 81.

${ }^{22}$ A special issue of the Nouvelle Révue de Psychanalyse, 32 (1985), edited by Jean-Bertrand Pontalis is devoted to "L'humeur et son changement." This collection of articles on the deep inward currents attests to the trend of metaphorization of fluid interiority in the wake of modern medicine.

${ }^{23}$ A. Mark Smith, "Getting the Big Picture in Perspectivist Optics," Isis, 72 (1981), p. 568-89, here p. 569, stresses the epistemic dimension of perspectivist optics as a cognitive model. 